\title{
OPEN Dynamics of cocoa fermentation and its effect on quality
}

\author{
Ana M. Calvo ${ }^{1}$, Blanca L. Botina ${ }^{1}$, Maria C. García ${ }^{1 凶}{ }^{1}$, William A. Cardona ${ }^{1}$, \\ Andrea C. Montenegro ${ }^{1} \&$ Jenifer Criollo ${ }^{2}$
}

Several research efforts on cocoa have been focused on parameters for controlling the transformation process to guarantee homogeneity and quality of cocoa beans, the main raw material in the chocolate industry. The main changes that determine the final quality of cocoa-and also the product's homogeneity-occur during fermentation, given the great number of factors that affect the process. This research seeks to identify the most relevant factors affecting quality in order to offer higherquality and more homogeneous cocoa for the chocolate industry. The dynamics of the fermentation process were observed in three contrasting locations, monitoring different variables and evaluating the final quality of the cocoa. Results show that temperature and $\mathrm{pH}$ profile are the key factors to be monitored and controlled in order to achieve high-quality cocoa beans.

Cocoa is the most important and valuable input for the chocolate industry ${ }^{1,2}$, which faces a new challenge every day, seeking to maintain the supply of standard products with non-standardized raw materials ${ }^{3}$. Cocoa composition and quality are affected by different factors, such as the genetic profile of the material ${ }^{4}$, environmental conditions of the production site, state of maturity of the beans, and processing conditions $s^{2,5-10}$. Therefore, cocoa producers and processors must also face this challenge since there are no guiding parameters for either the raw material or the transformation processes to facilitate obtaining a homogeneous product of high organoleptic attributes. The sensory analysis, largely affected by the profile of volatile aromas, determines rejection or acceptability, and the lower or higher value of cocoa in the market. Developing this aromatic profile throughout the production and processing of cocoa is highly complex and depends, in addition to the factors already listed, on a series of biochemical reactions that take place inside the bean once the embryo dies due to the action of temperature and the entry of organic acids. These acids also break the cell's membranes, allowing substrates and enzymes to mix, giving way to the oxidation of polyphenols, formation of tannins, catabolism of proteins, degradation of sugars, among many other changes. These acids and the increase in temperature that promote these changes inside the bean come from the fermentation of sugars and organic acids present in the pulp surrounding the cocoa bean.

Among the most important changes that cocoa undergoes during its fermentation, is the degradation of polyphenols (epicatechin, catechin, procyanidin, cyanidin and leucocyanidin, among others), which play an active role in the change of color, and its bitter, astringent taste ${ }^{11,12}$. Reduction of polyphenols takes place when they encounter polyphenol oxidases and peroxidases, enzymes responsible for catalyzing oxidation of polyphenols and formation of tannins-insoluble compounds with high molecular weight, also associated with astringent flavors in $\operatorname{cocoa}^{13,14}$. All degradation reactions are favored by high temperatures and long exposure times.

Proteins and amino acids also play a determinant role in the sensory quality of cocoa by being responsible for generating cocoa's aromas and flavor precursors. Voigt et al. ${ }^{15}$ and Biehl et al. ${ }^{16}$ propose the catabolism of proteins, mediated by the enzymatic action of aspartate-endoproteases and carboxypeptidases, as the factor responsible for the release of hydrophobic amino acids and hydrophilic oligopeptides associated with the generation of aromatic notes, and interacting subsequently with reducing sugars during cocoa roasting.

In accordance with the above paragraph, the decisive role that enzymes play in developing the final quality of cocoa is evident. Therefore, controlling variables such as temperature and $\mathrm{pH}$ will result in a better control of the process and therefore better quality and homogeneity of the product, since these two factors are those that have the greatest effect on enzyme activity. However, there are other factors that affect enzyme activity. Aspartate-endoproteases decrease with the degree of maturity of the cocoa bean, while the concentration of peroxidase increases with maturity. Thus, the state of maturity also affects the final quality of the cocoa ${ }^{15}$. The optimum working $\mathrm{pH}$ of the enzyme's aspartate proteases is 3.5 and 5.5 and of the carboxypeptidases is 5.8 , yet

${ }^{1}$ Corporación Colombiana de Investigación Agropecuaria - AGROSAVIA, Tibaitatá Research Center - Km 14 Route Mosquera-Bogotá, Cundinamarca, Colombia. ${ }^{2}$ Corporación Colombiana de Investigación Agropecuaria AGROSAVIA, Nataima Research Center - Km 9 Route - Espinal-Chicoral, Tolima, Colombia. ${ }^{\circledR}$ email: mcgarcia@ agrosavia.co 


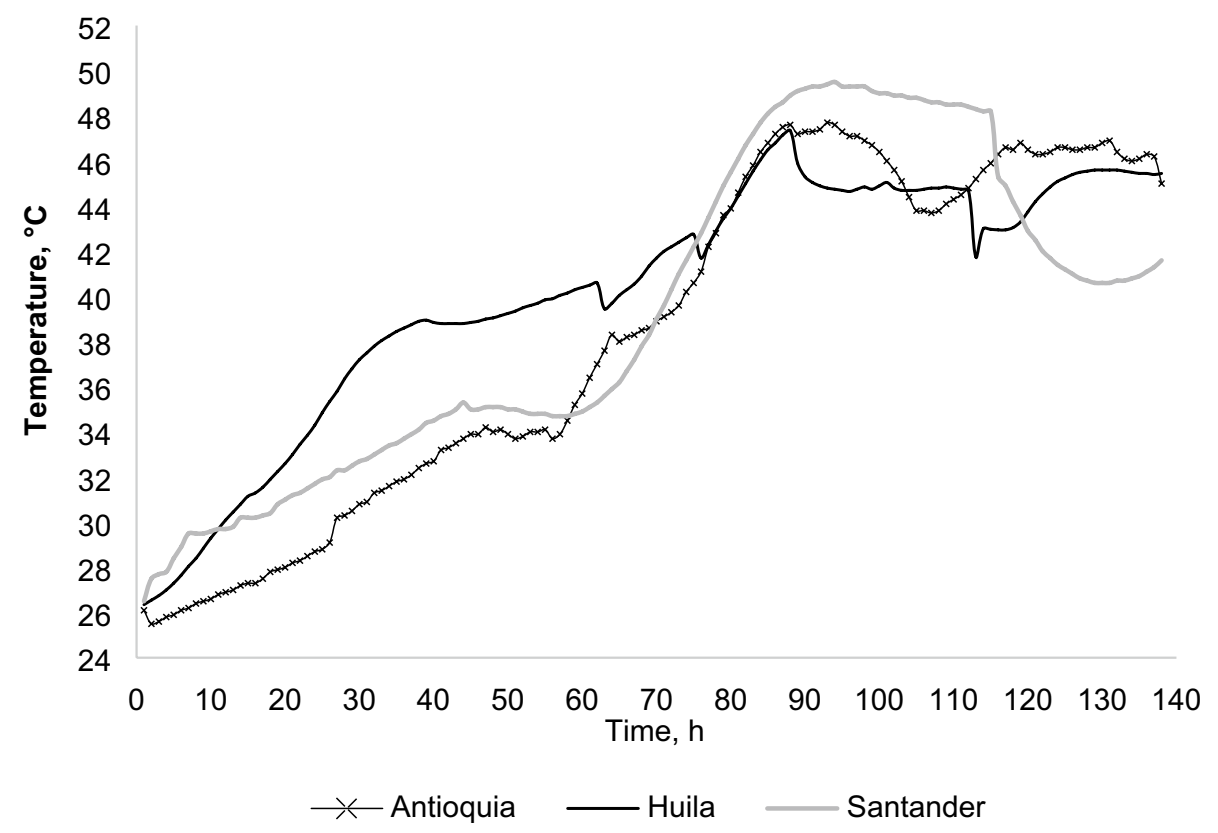

Figure 1. Temperature profile in the fermenter at the respective locations in the departments of Antioquia, Huila, and Santander.

since the two enzymes must act together, the optimum $\mathrm{pH}$ for the release of these aroma precursors has been found to be between 5.0 and $5.5^{17}$. In this $\mathrm{pH}$ range, polypeptides, corresponding to globulin $7 \mathrm{~S}$ or vicillin are selectively degraded subunits ${ }^{15,18}$. Therefore, suitable conditions for the release of these aroma precursors involve a combined action of aspartate-endoproteases and carboxypeptidases, a pH between 5.0 and 5.5 and the presence of $7 \mathrm{~S}$ globulins or vicillins. The maximum activity of peroxidase and polyphenol oxidase is a pH between 5 and 5.5 for the former and a $\mathrm{pH}$ of 7.0 for the latter.

Recent studies show that dietary polyphenols are effective antioxidants and play a significant role in the prevention of degenerative diseases ${ }^{19}$ (Manach et al. ${ }^{22}$ ). Consequently, these polyphenols can be considered part of the future of prevention and therapy in the area of medicine ${ }^{20}$. Cocoa polyphenols are associated with having beneficial effects on cardiovascular and inflammatory diseases, metabolic disorders, and cancer prevention ${ }^{3,21}$. Manach et al. ${ }^{22}$, Rodríguez-Carrasco et al. $^{3}$ draw attention to the origin of the cocoa and manufacturing process, which affect the polyphenols' content.

The objective of this research was to follow up on the biochemical and physicochemical changes that cocoa undergoes during its in-situ fermentation process, in three contrasting producing regions of the country, to test the hypothesis that monitoring the $\mathrm{pH}$ and temperature during fermentation can be an indicator of the quality of the cocoa obtained, regardless of the effect of the materials to be fermented and the production conditions.

\section{Results}

Fermentation system. Figure 1 illustrates the profile of temperatures measured in the center of the fermenter at each location. Ambient temperature and temperature on the surface of the fermenter were also recorded. Observation of the three temperatures showed that when the ambient temperature decreased, the difference between the temperature on the surface and the temperature in the center of the fermenter became greater, even if the fermenters were covered and located in closed spaces.

Results showed that Huila had the highest average environmental temperature, registering a value of $26.01{ }^{\circ} \mathrm{C}$, followed by Santander $\left(25.38^{\circ} \mathrm{C}\right)$ and Antioquia $\left(22.71^{\circ} \mathrm{C}\right)$. The average temperature of the fermenter throughout the process was $39.89^{\circ} \mathrm{C}$ in Huila, $39.43^{\circ} \mathrm{C}$ in Santander and $36.86^{\circ} \mathrm{C}$ in Antioquia.

As shown in Fig. 1, temperature changes in Antioquia and Santander were slower, while in Huila temperature increased significantly in the first hours of fermentation. Nonetheless, the highest fermentation temperatures were attained in Santander and Antioquia.

Physicochemical properties. Shell moisture. The locality factor showed no effect on moisture content of the cocoa bean shell. However, on the fifth day of fermentation, humidity was reduced ( $\mathrm{p}<0.05)$ by $9 \%, 16 \%$ and $21 \%$ for Antioquia, Huila and Santander, respectively (Fig. 2a).

Cocoa bean moisture. Cocoa beans from Santander showed significant differences in moisture content, compared to those from Huila and Antioquia $(\mathrm{p}<0.001)$. After $120 \mathrm{~h}$ of fermentation, moisture content decreased significantly $(\mathrm{p}<0.01)$ by $17 \%$ in Antioquia and Huila, while increasing $18 \%$ in Santander (Fig. 2 b). 
a.

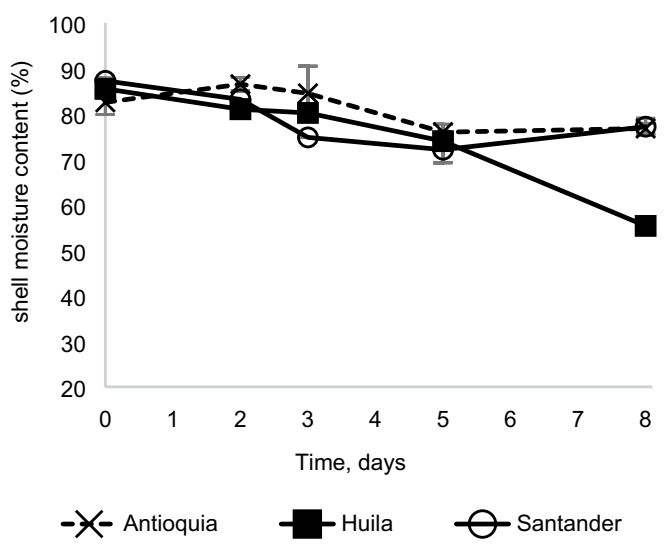

b.

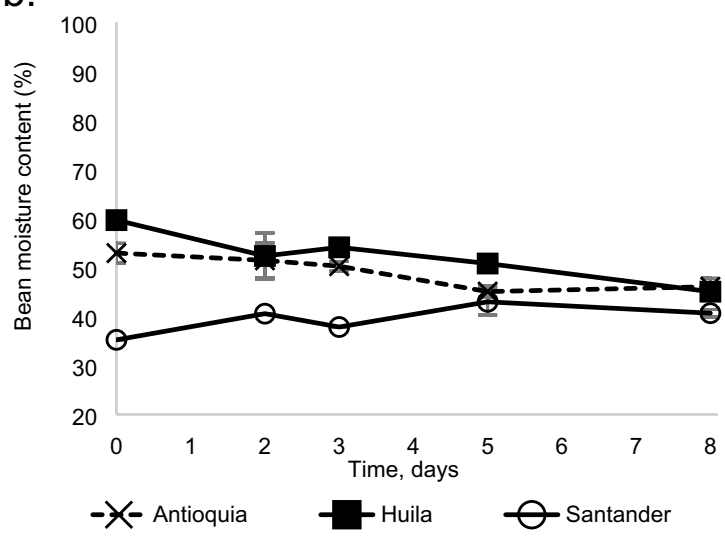

Figure 2. Moisture content of cocoa during fermentation carried out at three different locations: Antioquia, Huila, and Santander (a) shell and (b) beans.

TSS. Total soluble solids in the pulp did not show significant differences among localities or during fermentation, despite a reduction between 50 and $70 \%$ during the first two days of fermentation, remaining constant until the end of fermentation, with values between 4.5 and $6.5 \%$ for the three localities. A non-significant increase in TSS was observed in the beans, reaching values of $1.3 \% \pm 0.1$.

Acidity of the pulp. This variable did not report significant differences due to location or its dynamics; however, a peak in acidity was observed on the second day of fermentation for Antioquia and Santander, and on the third day for Huila, and then fell until the end of fermentation (Fig. 3a).

Acidity of the bean. No significant differences were found among sites. Acidity of beans increased significantly in Santander during the first two days of fermentation, while in Antioquia this increase took place on the third day. In the three localities the highest bean acidity was reached on the fifth day, with values of $0.26 \%$ in Antioquia, $0.21 \%$ in Santander and $0.18 \%$ in Huila (Fig. 3b).

Citric acid. There were no significant differences, although the three locations showed different behavior without a clear trend.

Lactic acid. The greatest significant differences, both in terms of location and fermentation, were found for lactic acid content. Nonetheless, after the first three days, the differences disappeared. In Antioquia initial lactic acid content was high (1.26\%), on the second day it decreased to $0.75 \%(\mathrm{p}<0.05)$ and increased slightly to $0.76 \%$ at the end of fermentation. In the case of Santander and Huila, lactic acid content increased significantly until days 2 and 3 ( $0.78 \%$ and $0.75 \%$, respectively), with values of $0.83 \%$ for Huila and $0.86 \%$ for Santander at the end of the fermentation process.

Acetic acid. There were differences in the dynamics, in which Santander presented a significant increase $(1.83 \%)(p<0.001)$ on the second day; while in Antioquia and Huila the significant changes $(\mathrm{p}<0.05)$ were reported on the third day (Fig. $3 \mathrm{c})$.

$p H$. During fermentation, $\mathrm{pH}$ decreased significantly $(\mathrm{p}<0.001)$ starting on the second day in Santander and on the third day in Antioquia $(\mathrm{p}<0.01)$ and Huila $(\mathrm{p}<0.05)$. At the end of fermentation, $\mathrm{pH}$ reached values of 5.1, 5.6 and 5.4, for Antioquia, Huila and Santander (Fig. 3d).

Ashes. Ash content was around 2.2 \pm 0.2 , decreasing by $15 \%, 8 \%$ and $23 \%$ in Antioquia, Huila and Santander, respectively. Differences were significant only for Santander and Huila $(\mathrm{p}<0.05)$.

Minerals. Minerals found in the highest concentrations in cocoa were zinc (46\%), iron (26\%), copper (24\%), manganese $(22 \%)$, and boron $(11 \%)$. The iron, copper, and zinc contents were significantly higher $(\mathrm{p}<0.05)$ for cocoa from Huila. During fermentation, iron, manganese, boron and zinc decreased by $32 \%, 19 \%, 17 \%$ and $12 \%$, respectively in Huila; while in Antioquia, iron, boron and zinc decreased by $12 \%, 9 \%$ and $7 \%$. Santander, on the other hand, reported an increase in iron (16\%) and boron (33\%). Potassium, phosphorus, magnesium and sulphur were found in smaller quantities in percentages of $0.83 \%, 0.41 \%, 0.24 \%$ and $0.12 \%$ respectively.

Fats. The content of fats in the cocoa was not significantly different among localities or in response to the fermentation process, with values of 53\% for Santander and Antioquia, and of $49 \%$ for Huila. 


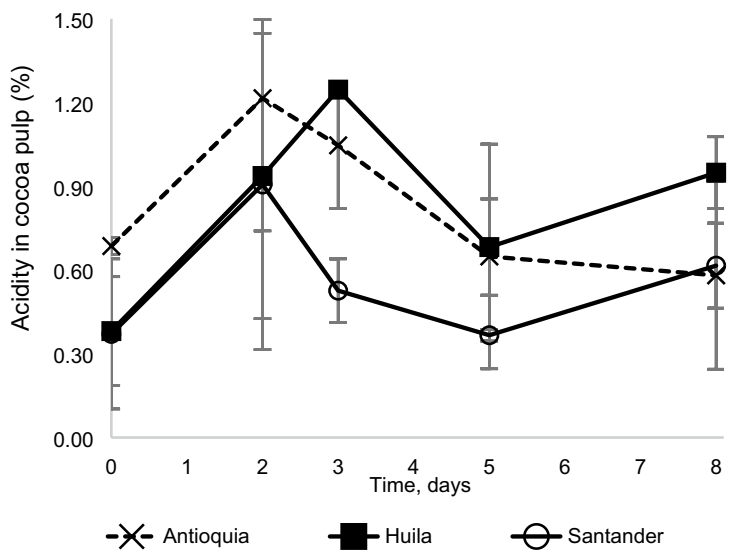

a

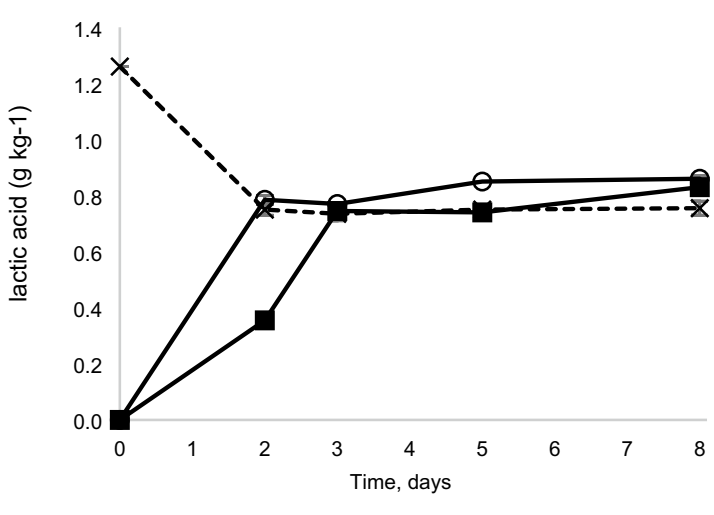

$-X-$ Antioquia

C

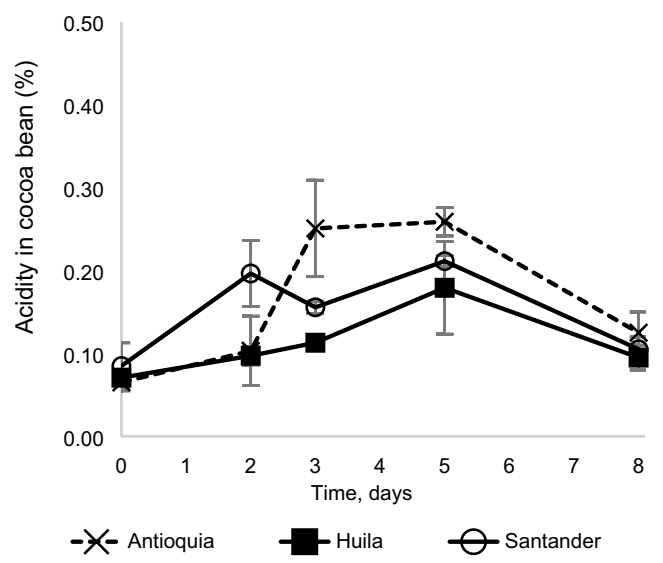

b

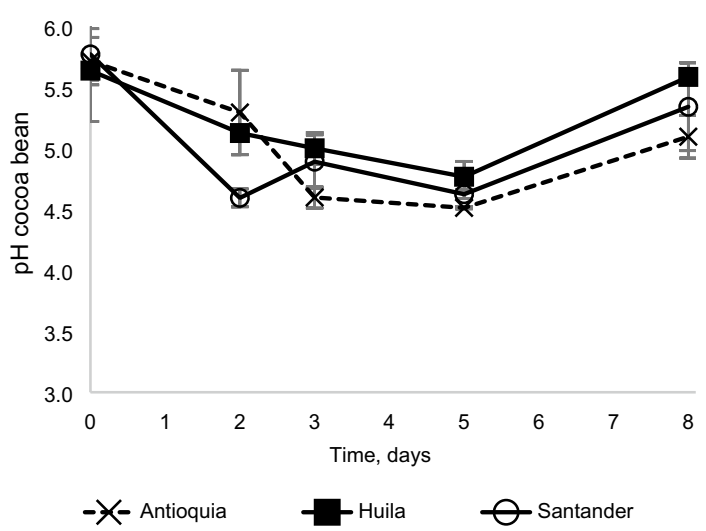

d

Figure 3. Dynamics of four variables during cocoa fermentation in three locations; Antioquia, Huila and Santander: (a) Acidity of the pulp, (b) acidity of the bean, (c) concentration of lactic acid, and (d) $\mathrm{pH}$ of the bean.

Fatty acid profile. These profiles did not present significant differences. The highest contents of fatty acids in the three locations were represented by palmitic (28.5\%), oleic (34.5\%) and stearic (33\%) acids and their changes during fermentation were less than $5 \%$.

Protein. The protein content of cocoa from Huila was significantly higher than that from Antioquia. In the three locations protein content showed a significant decrease $(\mathrm{p}<0.05)$ of $12 \%$ for Antioquia and Huila, and $16 \%$ for Santander, reaching values of $12.5 \pm 0.3 \%$ for the three locations.

Biochemical properties. Amino acids, sugars, polyphenols, methylxanthines have been included in this group, given their role in the quality of cocoa.

Total sugars (TS), reducing sugars (RS). No significant differences were found in TS content in raw cocoa from Antioquia (5\%), Huila $(2.8 \%)$ and Santander (4\%), however at the end of the fifth day of fermentation, these values were reduced by 55, 64 and $57 \%$, respectively. RS content in fresh beans from Antioquia (1.99\%) was significantly higher $(\mathrm{p}<0.05)$ than those from Huila. During fermentation, the RS decreased $(\mathrm{p}<0.01)$ in those cocoa beans for Antioquia (75\%) and Santander (79\%). Although the decrease for Huila was $94 \%$, it was not significant (Fig. 4).

Amino acids. Lysine (3.4\%), phenylalanine (1.9\%), alanine (2.5\%), valine (1.8\%), serine (1.6\%), glutamine $(1.4 \%)$, proline $(1.3 \%)$, leucine $(1.1 \%)$ were the amino acids present in greater proportions. Others like isoleucine $(1.07 \%)$, tyrosine $(0.75 \%)$, threonine $(0.43 \%)$, glycine $(0.13 \%)$, histidine $(0.05 \%)$ and arginine $(0.045)$ were found in lower proportions. Despite the low concentration they presented, the location and the fermentation process caused significant differences in the amino acids profile. In Antioquia and Huila, amino acids content 


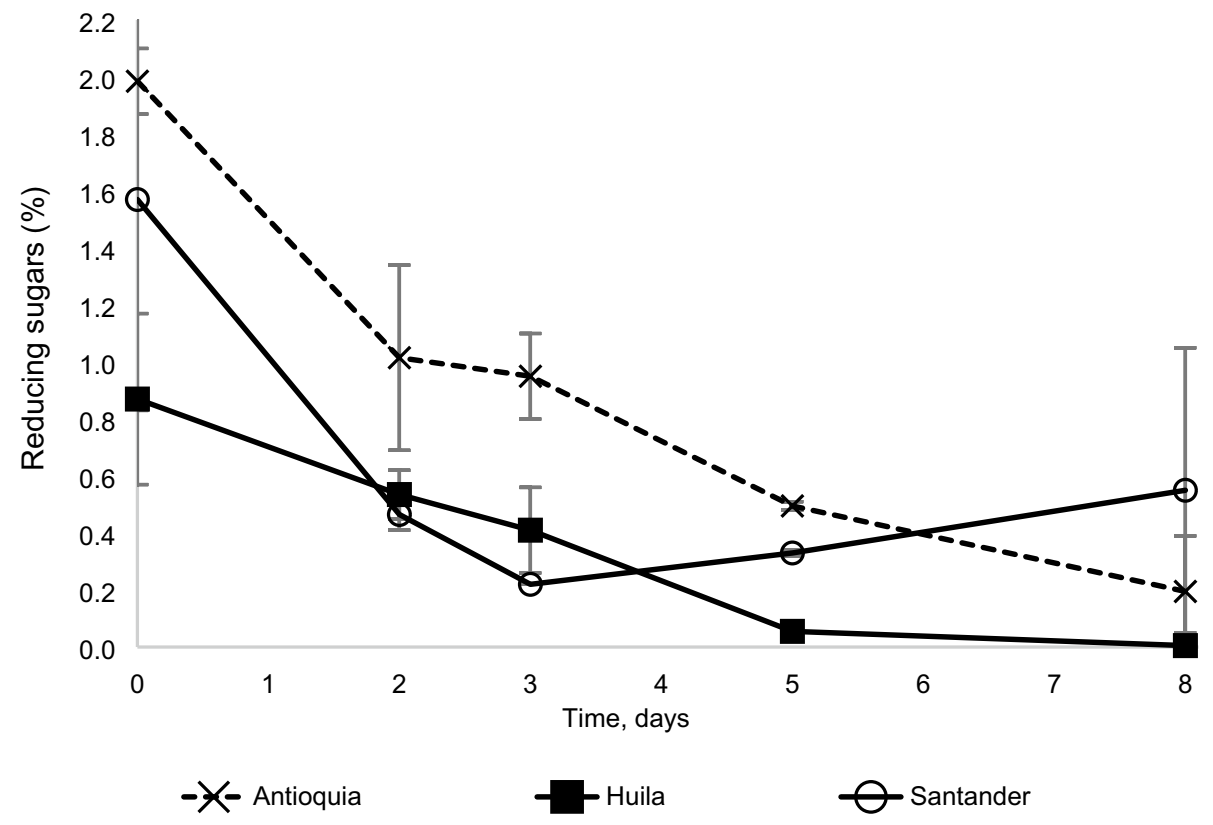

Figure 4. Dynamics of the content of reducing sugars during cocoa fermentation in three contrasting locations.

decreased significantly by about $11 \%$ on the fifth day, while in Santander, the reduction was higher, $14 \%$ for most of the amino acids present.

Total polyphenols (TP). Although the polyphenols content decreased $11 \%, 7 \%$ and $20 \%$ during the fermentation in each of the three locations Antioquia, Huila and Santander, respectively, there were no significant differences (Fig. 5a).

Catechin. This flavanol was reduced by $43 \%, 65 \%$ and $40 \%$ in Antioquia, Huila and Santander, respectively, due to the fermentation process. Nonetheless, only in Huila, was the reduction significant $(\mathrm{p}<0.05)$ (Fig. 5b).

Epicathequin. This polyphenol, although present in a higher proportion in fresh beans, was reduced by $51 \%$, $78 \%$ and $71 \%$ in Antioquia, Huila and Santander, respectively, on the fifth day of fermentation (Fig. 5c).

Procyanidins. This flavonoid was decreased by 38\%, 53\% and 67\% in Antioquia, Huila and Santander, during the fermentation (Fig. 5d). The reduction was significant $(\mathrm{p}<0.05)$ for the three locations.

Theobromine. No significant differences were identified, for either of the factors. The theobromine content in fresh beans was between 9.5 and $11 \mathrm{~g} \mathrm{~kg}^{-1}$ and at the end of the fermentation, decreased to values around $8.7 \mathrm{~g} \mathrm{~kg}^{-1}$ in the three locations.

Caffeine. The content of this methylxanthine in fresh beans was higher $(\mathrm{p}<0.05)$ in Antioquia, $\left(3.19 \mathrm{~g} \mathrm{~kg}^{-1}\right)$. After the fifth day of fermentation the reduction in caffeine content was 33, 28 and $6 \%$ for Antioquia, Huila and Santander, respectively, reaching values around $2.19 \mathrm{~g} \mathrm{~kg}^{-1}$ in the three locations.

Theobromine/caffeine, T/C. This correlation showed significant differences $(\mathrm{P}<0.05)$ between fresh beans from Antioquia and Huila; yet aforementioned differences disappeared during the fermentation process. At the end of the process this $\mathrm{T} / \mathrm{C}$ ratio reached values between 4.5 and 4.8 .

Antioxidant capacity. The antioxidant capacity did not present a clear behavior in the three locations. At the end of fermentation, the antioxidant capacity of the fermented cocoa beans decreased for Huila, but increased for Antioquia and Santander.

Aroma profile. This analysis was aimed at identifying compounds associated with some of the most recognized and valued aromas and flavors in the fine cocoa market; as well as the factors responsible for reducing its quality, such as acetic acid. In previous studies, 2,3-butanediol acetate, 2-phenyl ethanoate and ethyl dodecanoate were identified as the aromatic compounds prevailing in cocoa liquors coming from these localities (data not shown), with concentrations between 15 and $30 \mathrm{mg} \mathrm{L}^{-1}$ and conferring fruit notes to cocoa. The present study is focused on identifying other compounds that could make important differences. However, none 

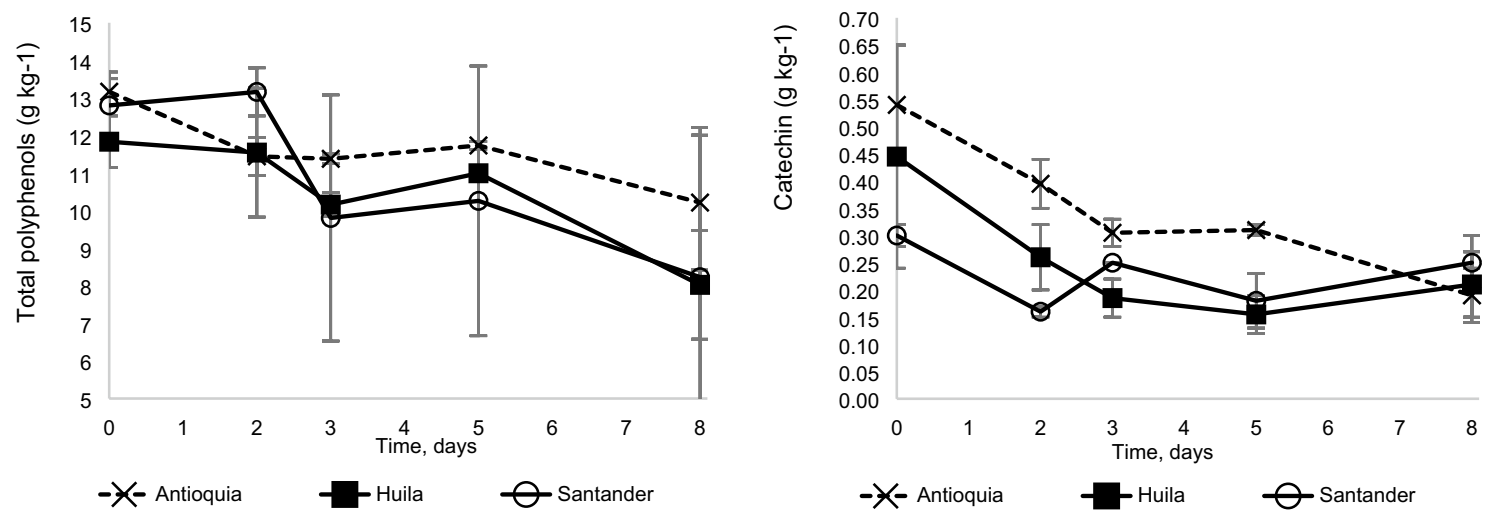

a

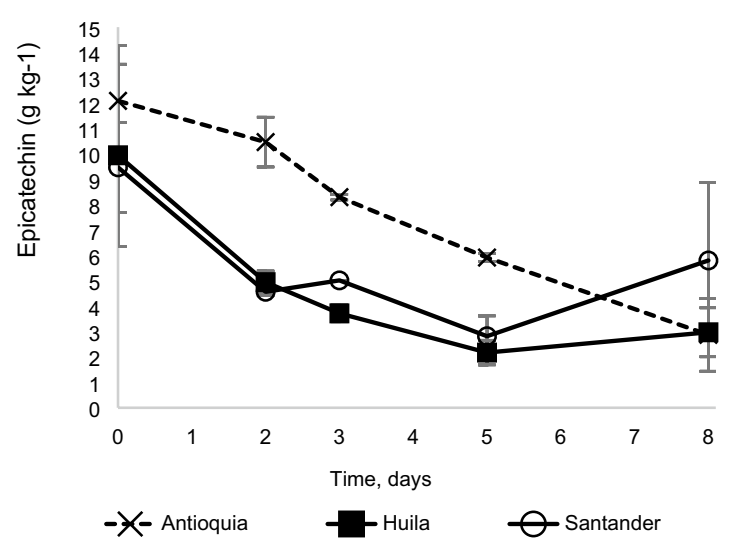

b

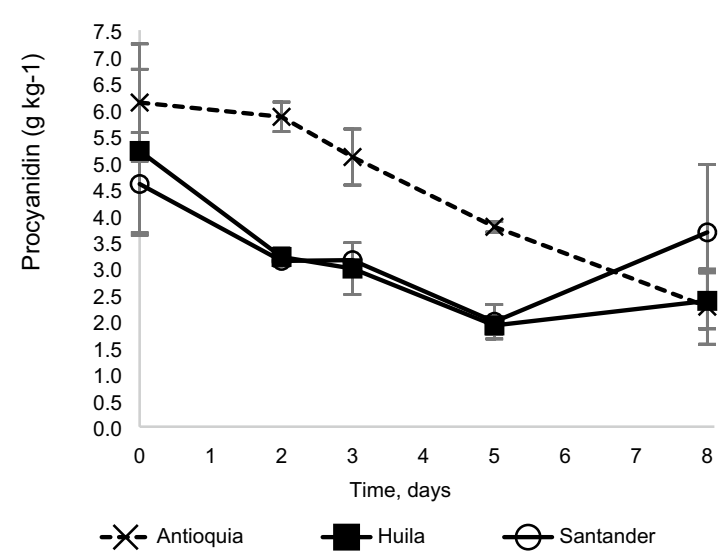

C

d

Figure 5. Dynamics of the polyphenols throughout the cocoa fermentation process in three locations: Antioquia, Huila, and Santander. (a) Total polyphenols, (b) Catechin, (c) Epicatechin and (d) Procyanidin.

were identified that exceeded the concentration of those previously found. Benzaldehyde and ethylbenzoate content decreased during fermentation, while 2,3,5-Trimethylpyrazine, Linalool oxide, and phenethyl alcohol increased. Nonetheless, none of these changes were significant. The compounds identified in higher concentration in cocoa from the different locations were acetic acid, 2,3-butanediol, linalool oxide, phenethyl alcohol, 2,3,4,5-tetramethylpyrazone. These compounds also maintained high concentrations in the cocoa liquor, except for 2,3,4,5-tetramethylpyrazone, which decreased significantly $(\mathrm{p}<0.01)$; while 2,3,5-Trimethylpyrazine increased significantly $(\mathrm{p}<0.01)$. In Huila, three compounds were outstanding: 2.5-Dimethylpyrazine with concentrations of $11.1 \pm 0.14$. $\mathrm{Mg} \mathrm{L}^{-1}$; linalool oxide $\left(5.85 \mathrm{mg} \mathrm{L}^{-1} \pm 1.0\right)$ and phenethyl alcohol $\left(7.5 \pm 4.8 \mathrm{mg} \mathrm{L}^{-1}\right)$. In Santander, the most prevalent compounds were phenethyl alcohol $\left(8.05 \pm 2.3 \mathrm{mg} \mathrm{L}^{-1}\right), 2,3$-dimethylpyrazine $\left(3.25 \pm 1.34 \mathrm{mg} \mathrm{L}^{-1}\right)$ and 2.3-butanediol $\left(2.45 \pm 0.78 \mathrm{mg} \mathrm{L}^{-1}\right)$. In Antioquia, the main compounds were phenethyl alcohol (6.3 $\left.\pm 4.8 \mathrm{mg} \mathrm{L}^{-1}\right) .2,3,4,5$-tetramethylpyrazone $\left(5.4 \pm 3.8 \mathrm{mg} \mathrm{L}^{-1}\right)$ and 2,3-butanediol $\left(4.1 \pm 2.4 \mathrm{mg} \mathrm{L}^{-1}\right)$. Other compounds identified were phenyl-acetaldehyde, which was present in a greater proportion in cocoa from Antioquia $(\mathrm{p}<0.05)$, but the content in liquor was significantly less $(\mathrm{p}<0.05)$; acetophenone was present in greater concentration in cocoa than in liquor in the localities of Antioquia and Huila ( $p<0.01)$; 2 -Acetyl pyrrole was present in liquor from Huila in greater proportions than in liquor from other locations $(\mathrm{p}<0.05)$.

Sensory profile. The Kruskal-Wallis test for the parameters evaluated by sensory analysis showed that the liquor from Huila had significantly higher cocoa $(\mathrm{P}<0.02)$ and nut $(\mathrm{P} \leq 0.01)$ aromas; and lower astringency $(\mathrm{P} \leq 0.01)$, acidity $(\mathrm{P} \leq 0.01)$, and bitterness $(\mathrm{P} \leq 0.01)$ than that from Antioquia. Cocoa produced in Santander had a remarkably similar profile to that of Huila, although it was significantly $(\mathrm{P} \leq 0.01)$ less acidic. As for the floral, fruit, green and panela or malt aromas, there were no significant differences among the liquors of the locations under study (Fig. 6).

Through Spearman's correlation analysis, a direct and significant relationship $(\mathrm{P}<0.02)$ was found among nut, fruit, and cocoa aromas (Table 1). In contrast, off-flavors associated with astringent and bitter profiles were inversely correlated with the nutty aroma. Acid flavors were directly associated with the over-fermented profile (other) and inversely with the unripe notes (Table 1). 


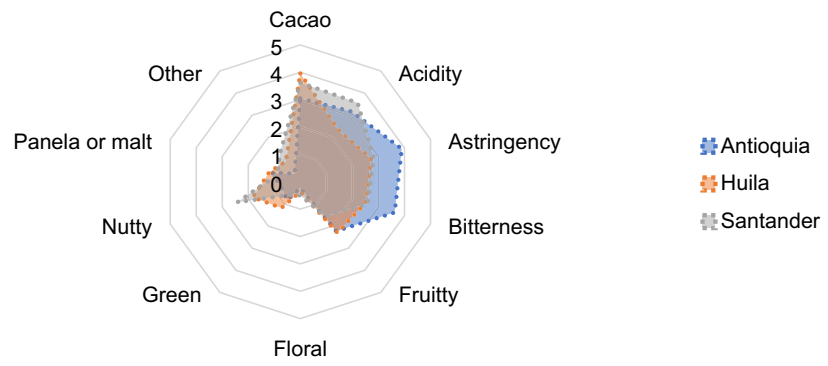

Figure 6. Sensory profile of cocoa liquor from Antioquia, Huila and Santander.

\begin{tabular}{|l|l|l|l|l|l|l|l|l|l|l|}
\hline \multicolumn{2}{|l}{ Correlation matrix among sensory variables } \\
\hline Flavors & 1 & 0.003 & $\mathbf{- 0 . 2 6 0}$ & -0.166 & 0.118 & 0.062 & 0.057 & $\mathbf{0 . 2 5 3}$ & 0.121 & 0.129 \\
\hline Cacao & 0.003 & 1 & 0.014 & 0.225 & 0.192 & 0.213 & $\mathbf{- 0 . 3 7 6}$ & 0.208 & 0.041 & $\mathbf{0 . 3 2 5}$ \\
\hline Acidity & $\mathbf{- 0 . 2 6 0}$ & 0.014 & 1 & $\mathbf{0 . 4 1 3}$ & -0.012 & 0.085 & 0.067 & $-\mathbf{0 . 3 6 5}$ & 0.014 & -0.059 \\
\hline Astringency & $\mathbf{- 0 . 1 6 6}$ & 0.225 & $\mathbf{0 . 4 1 3}$ & 1 & 0.085 & -0.033 & -0.077 & $\mathbf{- 0 . 3 5 7}$ & -0.052 & 0.073 \\
\hline Bitterness & 0.118 & 0.192 & $\mathbf{- 0 . 0 1 2}$ & 0.085 & 1 & 0.210 & 0.117 & $\mathbf{0 . 2 6 0}$ & 0.150 & 0.107 \\
\hline Fruity & 0.062 & 0.213 & 0.085 & -0.033 & 0.210 & 1 & 0.171 & 0.144 & $\mathbf{0 . 2 7 9}$ & -0.011 \\
\hline Floral & 0.057 & $\mathbf{- 0 . 3 7 6}$ & 0.067 & -0.077 & 0.117 & 0.171 & 1 & -0.041 & 0.065 & -0.229 \\
\hline Green & $\mathbf{0 . 2 5 3}$ & 0.208 & $\mathbf{- 0 . 3 6 5}$ & $\mathbf{- 0 . 3 5 7}$ & $\mathbf{0 . 2 6 0}$ & 0.144 & -0.041 & 1 & 0.105 & $\mathbf{0 . 2 5 6}$ \\
\hline Nutty & 0.121 & 0.041 & 0.014 & $\mathbf{- 0 . 0 5 2}$ & 0.150 & $\mathbf{0 . 2 7 9}$ & 0.065 & 0.105 & 1 & -0.079 \\
\hline Malt & 0.129 & $\mathbf{0 . 3 2 5}$ & $\mathbf{- 0 . 0 5 9}$ & 0.073 & 0.107 & -0.011 & -0.229 & $\mathbf{0 . 2 5 6}$ & $\mathbf{- 0 . 0 7 9}$ & 1 \\
\hline Other & 1 & 0.003 & $\mathbf{- 0 . 2 6 0}$ & $\mathbf{- 0 . 1 6 6}$ & 0.118 & 0.062 & 0.057 & $\mathbf{0 . 2 5 3}$ & 0.121 & 0.129 \\
\hline
\end{tabular}

Table 1. Spearman correlation among sensory variables. In bold, significant values $(\mathrm{P}<0.05)$. Other: refers mainly to the over-fermented profile.

\section{Discussion}

System conditions. In Antioquia, where the average temperature is lower than in Huila and Santander, the dynamics and the characteristics of aromatic and sensorial quality of liquor obtained through the fermentation process presented important differences. Although the increase in temperature is due to exothermic microbiological reactions that are generated during the fermentation of the beans, at lower ambient temperatures, heat loss from the fermenter is higher, reducing the temperature inside the fermenter. This brings consequences on the generation of flavor and aroma precursors, which then result in both a poor aromatic and sensory profile of the cocoa. Although the role of relative humidity is not so clearly defined, when this condition is very high and ventilation scarce, fungi development is favored and off-flavors are generated.

Physicochemical properties. Physicochemical changes in the pulp. When fermentation starts, the pulp is highly viscous, a condition that limits the entry of oxygen into the system, creating an anaerobic environment, which-added to the high content of sugars and organic acids-promotes the multiplication of yeasts ${ }^{23-25}$. Yeasts use sugars as a substrate, releasing different metabolites, such as ethanol, and energy that increases the temperature of the system, as shown in Fig. 1. The scarcity of oxygen, together with the presence of citric acid and residual sugars, favors the development of lactic bacteria ${ }^{26}$. These factors explain the rapid decrease in TSS found in the first 48 to $72 \mathrm{~h}$ of fermentation and the increase in temperature, between 38 and $45^{\circ} \mathrm{C}$. Additionally, the yeasts release pectinolytic enzymes, which break down the walls of the plant cells, increasing the fluidity of the pulp $\left.{ }^{5,27,28}\right)$. This greater fluidity, on the one hand, causes the pulp to drain out of the system, and with it, sugars, acids, and moisture-which was confirmed with the results obtained from the analysis of the pulp. On the other hand, the greater fluidness also favors the entry of oxygen into the system generating aerobic conditions, which, together with the reduction of acidity after the second day and the increase in temperature, favored the development of acidic-acetic bacteria ${ }^{26,29}$ - which in turn explains the presence and increase of different metabolites, among them acetic acid that increased until day 3 and 5 of fermentation. The results showed no significant differences among sites, although Huila reported a significant increase in acidity until the third day and, despite the drastic decrease suffered until day 5 , it ended up with the highest content.

Physicochemical changes in the bean. Moisture and sugars. The cocoa beans lost humidity during fermentation, initially due to the diffusion of moisture towards the outside of the grain, and later during the turning process, favored by the low relative humidity of the atmosphere. However, moisture content was high enough-at least $35 \%$, according to Apriyanto et al. ${ }^{30}$ - to favor the enzymatic processes that develop inside the almond. Sugar content ranged between 1.9 and 3.5\%, values that are within the $0.39 \%$ to $3.48 \%$ range defined by Peláez et al. ${ }^{31}$, Graziani de Fariñas et al..$^{32}$, Misnawi et al. ${ }^{23}$. Reducing sugars can decrease throughout the fermentation 


\begin{tabular}{|c|c|c|c|}
\hline Edaphoclimatic characteristics & San Vicente de Chucuri (Santander) & Maceo (Antioquia) & Rivera (Huila) \\
\hline Average annual temperature & $12->28^{\circ} \mathrm{C}$ & $20-26^{\circ} \mathrm{C}$ & $16-28{ }^{\circ} \mathrm{C}$ \\
\hline Average total annual rainfall & $1500-3000 \mathrm{~mm}$ & $2500-3000 \mathrm{~mm}$ & $1000-2000 \mathrm{~mm}$ \\
\hline Potential monthly evapotranspiration & $1400-1600 \mathrm{~mm}$ & $1400-1600 \mathrm{~mm}$ & $1200-1600 \mathrm{~mm}$ \\
\hline Relative humidity & $80-85 \%$ & $80-85 \%$ & $70-75 \%$ \\
\hline Thornthwaite water index & Humid & Humid & Subhumid humid \\
\hline Pluviometric Regime & Bimodal 2 & Bimodal 2 & Bimodal 6 \\
\hline $\begin{array}{l}\text { Average soil moisture (Thornthwaite water } \\
\text { index) }\end{array}$ & Humid $(80>=$ hi $>60)$ & Humid $(80>=h i>60)$ & Subhumid humid $(20>=h i>0)$ \\
\hline Soils & $\begin{array}{l}\text { Troporthents, Dystropets, and Eutopepts. } \\
\text { Deep to shallow soils with organic matter } \\
\text { adequate content, medium natural fertility, } \\
\text { topography strongly sloping to steep (25\%, } \\
\begin{array}{l}50 \% \text { and up to } 100 \%), \text { medium to high } \\
\text { susceptibility to erosion }\end{array}\end{array}$ & $\begin{array}{l}\text { Dystropepts and Troporthent, medium } \\
\text { to very deep soils, low natural fertility, } \\
\text { undulating to severely broken topogra- } \\
\text { phy (12-75\% slopes), and high erosion } \\
\text { susceptibility }\end{array}$ & $\begin{array}{l}\text { Troporthents, Ustorthents, Dystropepts. } \\
\text { Medium to shallow soil depth; from clayey } \\
\text { textures and sandy in granite areas; stony } \\
\text { in the profile, medium to low content of } \\
\text { organic matter, pH from } 4.5 \text { to } 5.0 \text {; strongly } \\
\text { undulating topography ( } 25 \%-60 \% \text { slope), } \\
\text { alternating with abrupt sectors ( } 100 \% \\
\text { slope), susceptibility to high to medium } \\
\text { erosion }\end{array}$ \\
\hline Rainfall Pattern & $\begin{array}{l}\text { Bimodal 2: Rainy season from March to } \\
\text { May and September to November } \\
\text { The mid-year dry season is not very marked }\end{array}$ & $\begin{array}{l}\text { Bimodal 2: Rainy season from March to } \\
\text { May and September to November } \\
\text { The mid-year dry season is not very marked }\end{array}$ & $\begin{array}{l}\text { Bimodal 6: Two rainy seasons at the begin- } \\
\text { ning and the middle of the year; Dry season } \\
\text { between June and August is much more } \\
\text { deficient than that of the first quarter }\end{array}$ \\
\hline
\end{tabular}

Table 2. Edaphoclimatic characteristics of the three study locations. Source: IDEAM ${ }^{56}$, Gómez et al. ${ }^{57}$.

by their participation as a source of energy in the different biochemical reactions and by the enzymatic breakdown of carbohydrates, releasing the respective mono-, di- and oligosaccharides ${ }^{33}$. On the other hand, reducing sugars can also increase during fermentation due to the hydrolysis of sugars caused by the acidification of the bean and the diffusion of reducing sugars from the pulp. Then, the final change in RS content is determined by the global balance among these two types of reactions.

Acidity and $\mathrm{pH}$. The results regarding acidity are in line with results found for lactic and acetic acid, and with what was proposed by De Vuyst and Weckx ${ }^{33}$ and Wacher ${ }^{26}$. Citric acid did not show significant changes, while lactic and acetic acids increased their concentration from the second to the fifth day of fermentation. These acids diffuse from the pulp to the bean and together with the increase in temperature, cause the death of the embryo, triggering a series of biochemical reactions ${ }^{28,34,35}$, which begin with rupture of the membranes of the internal compartments, favoring the mixing of their contents and the activation of enzymes. Enzyme activity is affected by both the temperature and the $\mathrm{pH}$ of the environment. Fermentation carried out in Huila presented a less drastic reduction of $\mathrm{pH}$ throughout the process, reaching minimum values of 4.8, compared to 4.6 and 4.5 presented by Santander and Antioquia, respectively; $\mathrm{pH}$ values later increased to values of 5.6 (Huila), 5.3 (Santander) and 5.1 (Antioquia). These small differences in $\mathrm{pH}$ can however make a significant difference in the final quality of the cocoa. According to Jackels and Jackels ${ }^{36}$, if $\mathrm{pH}$ of the beans reaches a range between 5.5 and 5.8 during the process of acidification, fermentation is considered to be incomplete,if $\mathrm{pH}$ is less than 4.75 the batch is considered to be over-fermented or very acidic; while a pH between 4.75 and 5.19 indicates a good fermentation process. Afoakwa et al. ${ }^{37}$ report that the generation of better aromatic and sensory profiles in cocoa is achieved when the $\mathrm{pH}$ is maintained between 5 and 5.2 and the temperature is kept below $40^{\circ} \mathrm{C}$. Biehl et al. ${ }^{38}$ affirm that under these conditions, the action of the aspartate endoproteases and carboxypeptidases enzymes is more efficient and that they achieve a selective release and breakage of proteins, which play a decisive role in the generation of aroma and flavor precursors. Fermentation in Huila was the closest to the favorable conditions specified by the above authors and which was corroborated by the biochemical reactions and the sensory profile of samples from this site.

Ashes and minerals. Values for ash content were below the $3 \%$ reported by Afoakwa et al. ${ }^{5}$ but its dynamic corresponded to those indicated by other authors ${ }^{5,39}$. This reduction can be explained by the ashes leaching with the mucilage that the system leaves, since most of the minerals are in the cocoa bean shell, which facilitates the exit of minerals from the system, especially the soluble ones ${ }^{40}$.

The acid soils from Huila, Table 2., allowed higher solubility of minerals such as $\mathrm{Fe}, \mathrm{Cu}, \mathrm{Mn}$, which was reflected in the higher presence of these minerals in fresh cocoa beans from Huila $\left(45,33,22 \mathrm{mg} \mathrm{Kg}^{-1}\right.$ respectively), than those from Antioquia (24, 13 and $17 \mathrm{mg} \mathrm{Kg}^{-1}$ ) and Santander (15, 8 and $\left.10 \mathrm{mg} \mathrm{Kg}^{-1}\right)$ respectively.

In terms of minerals, phosphorus content was found to be similar to that reported in cocoa from Ecuador ${ }^{41}$; and about double the content reported in cocoa from Ghana ${ }^{5,41}$. The calcium and potassium values were lower than those reported by Afoakwa et al. ${ }^{5}$ for Ghanaian cocoa- $0.14 \%$ and $2.3 \%$, respectively. However, reports by Torres et al. ${ }^{41}$ for cocoa from Ecuador and Ghana show values of $0.12 \%$ and 0.11 for calcium and $1.25 \%$ and $1.2 \%$ for potassium, respectively. The values are closer to those found in this study. Micronutrients such as zinc and copper presented values close to those reported for cocoa from Ecuador and Ghana (45 and $37 \mathrm{mg} \mathrm{kg}^{-1}$ for zinc, and 26 and $24 \mathrm{mg} \mathrm{kg}^{-1}$ for copper, respectively). Manganese content was low compared to that reported by Torres et al. ${ }^{41}$, who found values of 21 and $39 \mathrm{mg} \mathrm{kg}^{-1}$ in cocoa from Ecuador and Ghana, respectively. Mineral 
content in cocoa depends largely on the site's edaphic and climatic conditions, but there is no further information in the literature on the influence of these on the fermentation process, although it is known that the $\mathrm{Ca}$, for example, can play an important role in different biochemical reactions in plants. The presence of sodium, calcium, potassium, magnesium, and iron salts, among others, can affect color; other elements such as magnesium, zinc, and copper can act as co-factors in enzymatic processes ${ }^{42-44}$.

Fats and fatty acids. This research found fat contents between 49 and $54 \%$, which are within those reported in the literature, although values below 52\% are considered to be low. Normal fat content lies between 52 and 55\% and contents higher than $55 \%$ are considered high ${ }^{45}$.

Palmitic, oleic and stearic acids contribute with more than $90 \%$ to fatty acid content, but no significant differences were found among sites in terms of fatty acid content. These contribute to the development of the cocoa's aromatic profile, but large amounts $(>1.75 \%)$ of fatty acids result in bland consistencies and greater susceptibility to deterioration.

Biochemical properties. Proteins and amino acids. Fresh cocoa beans from the three locations presented protein content among $13 \%$ and $14 \%$, lower than those (16\% and $22 \%)$ reported by Afoakwa et al. ${ }^{37}$, yet in accordance with those values (10\% to $15 \%)$ stated by Marseglia et al. ${ }^{46}$. Proteins from cocoa beans are composed basically of globulins and albumins. During fermentation, protein content dropped to values between 11.5 and $13.9 \%$, which can be due to the vicilin (globulins) storage protein degradation by the action of an aspartic endoprotease and a serine carboxy(Exo) peptidase, which release hydrophilic peptides and hydrophobic amino acids $^{15}$ (De Vuyst and Weck ${ }^{33}$ ). The increase of hydrophobic amino acids such as leucine, alanine, phenylalanine observed in the present study, confirmed this proposal.

Total polyphenols. Polyphenols in fresh cocoa beans ranged from 11 to $13 \%$ for the three locations. These values are significantly higher than those reported by Miller et al. ${ }^{47}$ and Perea et al. ${ }^{48}$ of $1.3 \%$ and $6 \%$, respectively. The higher content found in the present study could be due to the type of material and its degree of maturity, among other factors ${ }^{49}$. However, during the fermentation process, the polyphenols decreased due to their diffusion from the storage cells and further oxidation by the action of polyphenol oxidase and the peroxidase released by the breakage of cell membranes inside the beans, which promotes the generation of highly insoluble tannins of high molecular weight ${ }^{13,14}$. The extension of these changes depends on two factors, the enzyme concentration and the advance of the fermentation. Peroxidase concentration and activity increase with the fruit ripeness and during the fermentation increase until the third day, after which decrease.

Cocoa polyphenols are mainly composed of proanthocyanidins (58\%-65\%), catechins (29-38\%) and anthocyanins (4\%). Epicatechins, procyanidins and catechins are polyphenols that play a decisive role in cacao quality and bioactivity. Although epicatechin was present in high amounts in fresh cacao beans, the fermentation decreased it between 51 and $78 \%$ in all three locations. Catechin and procyanidin declined between 40 and $63 \%$, which is in line with the study by Nazarudin et al. ${ }^{10}$. The high reactivity and selectivity of peroxidase for epicatechin explain the higher reduction in epicatechin. The change of epicatechin content is a progress fermentation indicator and its reduction contributes to less astringent cocoa products, favouring its quality ${ }^{49}$.

Antioxidant capacity. Although polyphenols are known as antioxidants, and procyanidins are often directly correlated with antioxidant capacity ${ }^{49-51}$, in this study, the epicatechin, catechin and procyanidins decreased significantly during fermentation, but the antioxidant capacity remained stable. Thus, antioxidant capacity is affected by other types of polyphenols or compounds not considered in this study.

Methylxanthines. Theobromine and caffeine constitute $99 \%$ of the alkaloid content in cocoa; the rest corresponds to theophylline and salsolinol. These compounds are associated with the bitter taste of cocoa. Contents of theobromine (8.4 to $11.4 \mathrm{~g} \mathrm{Kg}^{-1}$ ) and caffeine $\left(1.4\right.$ to $3.2 \mathrm{~g} \mathrm{~kg}^{-1}$ ) found in the present study were lower than those reported by other studies: 18 to $28 \mathrm{~g} \mathrm{~kg}^{-1}$ for theobromine and 3 to $10 \mathrm{~g} \mathrm{~kg}^{-1}$ for caffeine $\mathrm{e}^{45}$. Results on the evolution of theobromine during fermentation agree with findings of Brunetto et al. ${ }^{52}$ who proposed that theobromine increases during the first hours of fermentation and decreases after $72 \mathrm{~h}^{6,7}$. Davrieux et al. ${ }^{53}$ explain this initial increase by the fact that in the first days the mucilage contains theobromine that diffuses into the inner part of the grain. On the other hand, Krähmer et al. ${ }^{2}$, Palacios ${ }^{54}$ and Aprotosoaie et al. ${ }^{6,7}$ propose that the decreasing of this compound is due to the exudation of the beans during fermentation, favored by the increase in temperature. Concentrations of both caffeine and theobromine were reduced during fermentation. Theobromine/caffeine ratio depends on the genetic material, the state of maturity and the growing conditions ${ }^{6,7,53}$. The 3:7 theobromine/caffeine ratio found in fermentations in this study points out that raw cacao corresponds to Trinitarian cocoa materials.

Aromatic profile. Free amino acids, short-chain peptides and reducing sugars released during fermentation play a crucial role in the Maillard reactions during the roasting stage, generating mainly aldehydes and pyrazines, that along with esters, alcohols and ketones comprise more than 600 volatile compounds that confer cocoa, nutty, malt, fruity and flowery notes to cacao products. However, some acids and phenols can cause undesirable notes. The fermentation generated aroma precursors expressed during roasting and reduction of compounds like 2,3,4,5-tetramethyl pyrazine during the fermentation process can cause this to occur. This pyrazine showed higher contents in fresh cocoa beans than in cocoa liquor. Cocoa liquor from Huila presented 2,5-dimethyl pyrazine, linalool oxide and phenethyl alcohol, which conferred cocoa, floral and fruity notes to 
the cocoa liquor. However, cocoa liquor from Huila was also highly acidic, associated with the presence of acetic acid. In the case of Antioquia and Santander, fresh cocoa beans showed a high content of acetic acid and tetramethylpyrazine. During fermentation in Antioquia and Santander, acetic acid diminished by $74 \%$ and $67 \%$, and tetramethylpyrazine by $66 \%$ and $94 \%$ respectively. Meanwhile, other compounds such as dimethyl and trimethyl pyrazine, linalool oxide and phenethyl alcohol increased during fermentation.

Sensory analysis. Cocoa liquor is the paste derived from cocoa beans, and Fig. 6 depicts its aroma and flavour intensity. The cocoa liquor from Huila had a better sensory profile than that of Antioquia and Santander, evidenced in its powerful cocoa aroma, nutty notes, less astringent sensation, and neither sour nor bitter taste. The fermentation of the cocoa generates a $40 \%$ reduction in the content of initial polyphenols associated with the level of bitterness and astringency in the cocoa liquor, which allows the expression of specific aromas and explains the direct and significant relationship between the nutty, fruity, and cocoa aromas, found in Spearman's correlation analysis, and that can be an indicator of efficient fermentation processes.

The sensory profile is the most representative indicator of cocoa quality since each parameter evaluated (texture, colour, aroma, flavour) consolidates the effects of all changes occurring from production to processing. The study confirmed cocoa beans from Huila to be the best quality and also the best fermentation performance supported in (1) the reduction of epicatechin, catechin and procyanidins that led to a reduced sensation of astringency and bitter taste, and appropriate colour; (2) the degradation of proteins and the release of hydrophobic amino acids and hydrophilic oligopeptides that led to a better generation of aroma and flavour precursors. All these changes are reflected in the cocoa liquor, after drying and roasting.

These excellent profiles shown by the cocoa process from Huila, are explained by a better development in the dynamics of $\mathrm{pH}$ and temperature shown during cocoa fermentation, and whose effect is decisive on the biochemical reactions that occur inside the bean and on the dynamics of fermentation. Temperature and $\mathrm{pH}$ strongly affect the activity of the enzymes that regulate the crucial biochemical changes inside the bean, such as the oxidation of polyphenols and the catabolism of proteins. Temperature and $\mathrm{pH}$ of the medium largely determine the sequence of microbiological groups and metabolites responsible for triggering changes within the grain during fermentation.

The fruity and floral notes present in the liquors from the three departments are associated with the presence of esters and alcohols, which are stable to the processes of transformation of the grain ${ }^{55}$, and qualify them as both fine quality and of aroma.

\section{Conclusions}

The study of the cocoa fermentation process in the three different production areas in Colombia showed that there are two stages involved in the final quality of the bean: the first in which the sugars and acids are fermented to generate the metabolites and second, the conditions that cause the death of the embryo and trigger a whole series of reactions inside the bean. These biochemical reactions are responsible for the generation of aroma and flavor precursors, which will later build the final quality of cocoa and will be consolidated in the sensory and aromatic profile of the same. In these two stages, both the temperature and $\mathrm{pH}$ profiles of the system play a determining role. In fact, they should be the principal variables to be monitored and controlled. These two variables have a direct effect both on the biochemical reactions inside the grain, thanks to their effect on the activity of the respective enzymes and on the development of fermentation-by affecting both the sequence of microorganisms that take part in the fermentation process and the metabolites they release, and the changes that this trigger inside the grain.

\section{Materials and methods}

Location. This research was carried out in the three most important cocoa-producing agroecological zones in Colombia: (a) municipality of San Vicente de Chucurí (coordinates: 6 $52^{\prime \prime} 57^{\prime \prime} \mathrm{N}$; $73^{\circ} 24^{\prime \prime} 46^{\prime \prime} \mathrm{O}$ ) in the mountains of the department of Santander, (b) municipality of Rivera (coordinates: $2^{\circ} 46^{\prime} 38^{\prime \prime} \mathrm{N} ; 7^{\circ} 15^{\prime} 19^{\prime \prime} \mathrm{O}$ ) in the inter-Andean valleys of the department of Huila, and (c) municipality of Maceo (coordinates: $6^{\circ} 33^{\prime} 12^{\prime \prime} \mathrm{N} 7$; $4^{\circ} 47^{\prime} 14^{\prime \prime} \mathrm{O}$ ) in the marginal coffee zone in the department of Antioquia. The edaphoclimatic characteristics of each zone are described in Table 2. The purpose was to compare and determine the effect of edaphoclimatic conditions and genetic material on the final quality of cocoa. To achieve this objective, a representative farm was selected in each agroecological zone, where a great diversity of hybrids and clones were found in each region. Considering that the three sites (Maceo, San Vicente de Chucurí and Rivera) are representative of Colombian cocoa production, this document will refer to the departments where they are located: Antioquia, Santander and Huila, respectively. The objective of extrapolating from site to department is estimating the quality of cocoa obtained by the interaction with the environment at the scale of cocoa growing regions in Colombia.

Cocoa beans embody the raw material to produce cocoa-based products. Cocoa beans are the seeds of the fruits of the cocoa tree (Theobroma cacao L.) and consist of two cotyledons or nibs and an embryo, all enclosed in a shell. They are built for storage cells contained proteins, starch, and fat globules; and for pigmented cells, which comprise polyphenols and methylxanthines.

Monitoring of fermentation conditions. Both fermentation room and fermenter conditions were monitored.

Temperature $(T)$ and relative humidity $(R H)$. ThermaData HTD (Worthing, United Kingdom) humidity and temperature loggers were placed in the fermentation rooms to monitor T and RH. The logger was hung $0.30 \mathrm{~m}$ from the centre of the roof, far from any surface. This information is relevant to understand how environmental 
conditions can affect fermentation performance. Low external temperature can generate a loss of heat from the fermenter system to the environment affecting the fermentation performance. Loggers registered the $\mathrm{T}$ and $\mathrm{RH}$ from the beginning until the end of the process, every $20 \mathrm{~min}$.

Fermentation temperature. To get more accurate information about the fermentation process, the profile temperature along the fermentation process was recorded using a Testo 5607351 (Testo SE \& Co, Lenzkirch, Germany). Thermocouples installed in the fermenter registered the temperature of cocoa grains under fermentation every $20 \mathrm{~min}$.

Monitoring fermentation dynamics. Physicochemical analysis. Moisture of the shell and the bean. A slight modification of the AOAC Method 931.04 was used to determine moisture content. For this purpose, 20 beans were taken in each sampling from three different points of the fermenter. The testa or bean shell, to which the pulp is attached, was removed. Both shell and beans were placed in glass capsules and weighed separately. They were placed in a Memmert drying oven (Model VM400, Schwabach, Germany) at $103{ }^{\circ} \mathrm{C}$ for approximately $48 \mathrm{~h}$, and were then transferred to the dryer at 12 -h intervals and weighed until a constant weight was obtained.

Total soluble solids ( $\left.{ }^{\circ} \mathrm{Brix}\right)$. AOAC $932.12^{58}$ protocols were followed to determine total soluble solids, expressed in ${ }^{\circ}$ Brix, using a digital refractometer (Atago PAL-1, Tokyo, Japan). One drop of the previously homogenized extract was placed on the equipment's prism to record the value.

Sugars (reducing and non-reducing). Sugars were determined by liquid chromatography following the methodology proposed by Murillo et al. ${ }^{59}: 1 \mathrm{~g}$ of cocoa sample was dissolved in $10 \mathrm{~mL}$ of a $0.2 \%$ (w/v) benzoic acid solution and centrifuged at $5000 \mathrm{rpm}$ for $30 \mathrm{~min}$. Finally, the supernatant was filtered with a PDVF $0.22 \mu \mathrm{m}$ syringe filter and injected into the Thermo Dionex Ultimate 3000 HPLC liquid chromatograph (Thermo Fisher Scientific Inc. Asheville, United States) equipped with degasser, automatic injector, an ICE COREGEL 107-H column (Transgenomic) and an RI RefractoMax520 detector, with an injection volume of $20 \mu \mathrm{L}$.

Titratable acidity of bean and pulp. The protocol established by AOAC $942.15^{60}$ was followed, using a Hanna potentiometer (HI2020-01, Woonsocket, Rhode Island, United States), to determine acidity of an acid-base titration of $2 \mathrm{ml}$ of the previously diluted bean extract, which was titrated with $\mathrm{NaOH}(0.03 \mathrm{~N})$ until a $\mathrm{pH}$ of 8.2 was obtained. The titratable acidity was quantified as the equivalent weight of citric acid.

Organic acids (citric, lactic and acetic). $1 \mathrm{~g}$ of cocoa was weighed and dissolved in $\mathrm{HCl}$ by adjusting the $\mathrm{pH}$ to 2.3. Finally, it was centrifuged and the supernatant was injected into a Thermo Dionex ultimate 3000 HPLC system (Thermo Fisher Scientific Inc. Asheville, United States) equipped with degasser, automatic injector, an ICE COREGEL 107-H column (Transgenomic) and an RI RefractoMax520 detector, with an injection volume of $20 \mu \mathrm{L}$ and a flow rate of $0.6 \mathrm{~mL} / \mathrm{min}$.

$\mathrm{pH}$. The AOAC $943.02^{61}$ potentiometric method was used to determine $\mathrm{pH}$, with a Hanna (HI202001, Woonsocket, Rhode Island, United States) $\mathrm{pH}$ meter, previously calibrated, by introducing the equipment's electrode directly in the juice extracted from the pulp and then recording the value.

Ashes. The official AOAC $942.05^{62}$ method was followed to determine ash content: $0,1 \mathrm{~g}$ of the dried and ground sample was introduced into previously tared porcelain crucibles which were taken to a Thermo Scientific Thermolyne FD1540M-33 muffle (Thermo Fisher Scientific Inc., Asheville, United States), at $600{ }^{\circ} \mathrm{C}$ for $4 \mathrm{~h}$. Once the flask had cooled, it was transferred to a desiccator until it reached room temperature for weighing.

Minerals. Atomic absorption spectrometry was used to determine mineral content of phosphorus (P), potassium $(\mathrm{K})$, calcium $(\mathrm{Ca})$, magnesium $(\mathrm{Mg})$, sodium $(\mathrm{Na})$, sulfur $(\mathrm{S})$, iron $(\mathrm{Fe})$, copper $(\mathrm{Cu})$, manganese $(\mathrm{Mn})$ and zinc $(\mathrm{Zn}): 0.5 \mathrm{~g}$ of the dried and ground sample was weighed and mineralized by the acid digestion method in a closed system (Milestone Ultrawave microwave) with nitric acid and hydrogen peroxide. One milliliter of the mineralization extract was added to a $50 \mathrm{ml}$ beaker with $9 \mathrm{ml}$ of a $0.040 \%$ lanthanum chloride solution to complete a final volume of $10 \mathrm{ml}$. The concentration of each mineral was determined by atomic absorption spectrometry, using calibration curves for each element.

Protein. The micro Kjeldahl method based on AOAC $960.52^{63}$ was used to measure crude protein content by determining the nitrogen content, taking $0.1 \mathrm{~g}$ of a dried and ground sample.

Fats. The Soxhlet gravimetric method proposed in AOAC $963.15^{64}$ was used to determine fat content, using petroleum ether for solvent extraction.

Biochemical analysis. Fatty acid profile. Following the methodology proposed in the ISO 5508:1990 norms, fatty acids were analyzed by obtaining and quantifying their methyl esters using gas chromatography with flame ionization detector (GC-FID). The chromatographic analysis of the sample was performed in a gas chromatograph (Agilent Technologies 7890 N, Santa Clara, United States), reference of the column used was HP-88 (J \& W Scientific Folsom $60 \mathrm{~m} \times 0.25 \mathrm{~mm} \times 0.20 \mu \mathrm{m})$ and the injection was performed in split mode (10:1). 
Amino acids. The cocoa sample was dissolved in $6 \mathrm{~N} \mathrm{HCl}$ and placed in reflux for $22 \mathrm{~h}$. It was then neutralized and brought to a $\mathrm{pH}$ of 2.3 with $0.1 \mathrm{~N} \mathrm{HCl}$. Subsequently, the amino acids were derivatized with o- phthalaldehyde and injected into the Dionex ultimate 3000 HPLC chromatograph (Thermo Fisher Scientific, Waltham, MA, United States) controlled by the Chromeleon 7.2 software, equipped with a reversed-phase column (Zorbax Eclipse $\mathrm{XDB}$, measuring $150 \mathrm{~mm} \times 2.1 \mathrm{~mm}$ ) with a particle size of $5 \mu \mathrm{m}$.

Total polyphenols. Following the procedure described by Wollgast ${ }^{65}$, the Folin-Ciocalteu method was used to measure total polyphenols, using gallic acid as a reference standard to make the calibration curve and thus determine the concentration of gallic acid associated with the absorbance at $765 \mathrm{~nm}$ in a Thermo Scientific UV-VIS spectrophotometer (Genesys 10UV Thermo Electron, Waltham, MA, United States). Results were reported as gallic acid equivalents on a dry base.

Catechin, epicatechin, procyanidin $(\mathrm{B} 1+\mathrm{B} 2)$ and methylxanthines (caffeine and theobromine). The methodology proposed by Carrillo et al. ${ }^{66}$ was followed, using the calibration curves of the respective reference substances. A Dionex ultimate 3000 HPLC system (Thermo Fisher Scientific, Waltham, MA United States) controlled by the Chromeleon 7.2 software was used for analysis of compounds. The system is equipped with a reversed-phase column (Zorbax Eclipse XDB measuring $150 \mathrm{~mm} \times 2.1 \mathrm{~mm}$ ) with a particle size of $5 \mu \mathrm{m}$. Theobromine and caffeine were quantified using a UV detector at $273 \mathrm{~nm}$.

Antioxidant capacity. The DPPH (2,2-diphenyl-1-picrylhydrazine in 2,2-diphenyl-1-picrylhydrazine) assay reported by Sharma and Bhat ${ }^{67}$ was used to measure antioxidant capacity, deploying the antioxidant action of compounds containing - $\mathrm{OH}$ groups that discolor the DPPH reagent,this effect was evaluated by decreasing absorbance at $517 \mathrm{~nm}$ in a Thermo Scientific UV-VIS spectrophotometer (Genesys 10UV Thermo Electron, Waltham, MA, United States), using ascorbic acid as the reference pattern.

Aromatic profile. The HS-SPME technique by gas chromatography with flame ionization detector (GC-FID) was used to analyze volatile compounds. Linalool, 2,3-butanediol, 2,5-dimethylpyrazine, 2-phenethylacetate, acetophenone, 2,3,5-trimethylpyrazine, ethylbenzoate, phenethyl alcohol, acetyl pyrrole, tetramethylpyrazine, benzaldehyde, phenylacetaldehyde (Sigma-aldrich) and acetic acid (Merck) were used as reference standards. The analysis was performed on a gas chromatograph (GC) 7890 (Agilent Technologies, Santa Clara, United States) with a flame ionization detector (FID). The column used in the analysis was HP-5 (5\%-polyphenol-95\% dimethylsiloxane, $30 \mathrm{mx} 0.32 \mathrm{~mm} \times 0.25 \mu \mathrm{m}$ Agilent J\&W) in a 3:1 split mode.

Sensory profile. Sensory properties of cocoa liquor were evaluated by seven trained panelists (age 22 and 45), under informed consent. The panelists make part of the sensory evaluating panel of cocoa liquor and cocoabased products from the Nataima Research center. The analysis followed the protocols established by the Sensory evaluation laboratory protocols of Nataima research center of AGROSAVIA. All methods were carried out in accordance with relevant guidelines and regulations. A Quantitative Descriptive Analysis (QDA) was applied to evaluate the flavor attributes ranges in a $0-10$ scale, where 0 means absent and 10 , highly pronounced or present. This research did not carry out any biomedical study or any experimentation with humans subjects. The aim was to bring light to the fermentation process to ensure the quality and homogeneity of cocoa-based products. Panelist only tastes the samples (less than $1 \mathrm{~g}$ ), to qualify the following sensory attributes cocoa flavor, astringency, bitterness, acidity, sourness, fruity, floral, nutty, panela, caramel, and malt, managing to identify the state of fermentation of the samples and possible off-flavors conferred by inappropriate processing, such as abrupt drying or low fermentation percentages. The cocoa liquor evaluated at $45^{\circ} \mathrm{C}$ was obtained after roasting at $125^{\circ} \mathrm{C}$ for $15 \mathrm{~min}$ in a Quantik rotary toaster, removing the husk and, grinding the beans in a Kitchen brand blade processor for $20 \mathrm{~min}$ until a paste with a particle size of 70 microns was obtained. Duplicate samples of the liquor were evaluated in three tasting sessions to arrive at the sensory profile.

Statistical analysis. All the analyses were carried out by triplicate and the Generalized Linear Mixed Models (GLMMs) were used to estimate fixed effects and interactions. The Backward procedure based on a 5\% $\mathrm{p}$-value was used to select a reasonable model for each variable. Comparisons of factor levels were made by means of Fisher's least-squares means using Student t-statistics based on the Satterthwaite approximation (effective number of degrees of freedom). Each response variable was evaluated at the beginning of fermentation (day 0 ), on days 2, 3, 5 (end of fermentation) and on day 8 (drying). The liquor obtained was compared-in terms of variables associated with the aroma profile-with the unfermented cocoa in the different locations. In each model, the start of fermentation was selected as the control time to verify if the increases or decreases in time were significant according to the ' $\mathrm{t}$ ' test. To verify if each model was adjusted and the normality of the data, the distribution of Pearson's residuals in each variable was evaluated, indicating that the Gaussian distribution was adequate for all variables. These models were designed using Proc GLIMMIX from the Statistical Analysis System (SAS) V. 9.4. Considering that the variables associated with the sensory analysis were not normal, the Kruskal-Wallis test was used at $5 \%$ for each profile identified in the cocoa liquor obtained at each location, using the SAS V. 9.4 Proc nparlway procedure. Finally, the Spearman correlation was applied to the sensory variables, selecting the significant relationships based on a value of $\mathrm{P} \leq 0.05$, using the SAS V. 9.4 PROC CORR procedure. 
Received: 21 October 2020; Accepted: 29 July 2021

Published online: 18 August 2021

\section{References}

1. Ho, V. T. T., Zhao, J. \& Fleet, G. The effect of lactic acid bacteria on cocoa bean fermentation. Int. J. Food Microbiol. 205, 54-67. https://doi.org/10.1016/j.ijfoodmicro.2015.03.031 (2015).

2. Krähmer, A. et al. Fast and neat Determination of biochemical quality parameters in cocoa using near infrared spectroscopy. Food Chem. 181, 152-159. https://doi.org/10.1016/j.foodchem.2015.02.084 (2015).

3. Rodríguez-Carrasco, Y., Gaspari, A., Graziani, G., Santini, A. \& Ritieni, A. Fast analysis of polyphenols and alkaloids in cocoabased products by ultra-high performance liquid chromatography and Orbitrap high resolution mass spectrometry (UHPLC-QOrbitrap-MS/MS). Food Res. Int. 111, 229-236. https://doi.org/10.1016/j.foodres.2018.05.032 (2018).

4. Sánchez, I., Zárate, L. A., Gallego, G. \& Tohme, J. Análisis de la diversidad genética de accesiones de Theobroma cacao L. del banco de conservación a cargo de Corpoica. Cienc. Tecnol. Agropec. 8(2), 26-31. https://doi.org/10.21930/rcta.vol8_num2_art:91 (2008).

5. Afoakwa, E. O., Quao, J., Takrama, J., Simpson, A. \& Kwesi, F. Chemical composition and physical quality characteristics of Ghanaian cocoa beans as affected by pulp pre-conditioning and fermentation. J. Food Sci. Technol. 50(6), 1097-1105. https://doi.org/ 10.1007/s13197-011-0446-5 (2013).

6. Aprotosoaie, A. C., Luca, S. V. \& Miron, A. Flavor chemistry of cocoa and cocoa products: An overview. Compr. Rev. Food Sci. Food Saf. 15, 73-91. https://doi.org/10.1111/1541-4337.12180 (2016).

7. Aprotosoaie, A. C., Miron, A., Trifan, A., Luca, V. S. \& Costache, I. I. Review. The cardiovascular effects of cocoa polyphenols: An overview. Diseases 4(4), 39. https://doi.org/10.3390/diseases4040039 (2016).

8. Camu, N. et al. Influence of turning and environmental contamination on the dynamics of populations of lactic acid and acetic acid bacteria involved in spontaneous cocoa bean heap fermentation in Ghana. Appl. Environ. Microbiol. 74(1), 86-98. https:// doi.org/10.1128/aem.01512-07 (2008).

9. Kadow, D., Bohlmann, J., Phillips, W. \& Lieberei, R. Identification of main fine or flavour components in two genotypes of the cocoa tree (Theobroma cacao L.). J. Appl. Bot. Food Qual. 86, 90-98. https://doi.org/10.5073/JABFQ.2013.086.013 (2013).

10. Nazaruddin, R., Seng, L. K., Hassan, O. \& Said, M. Effect of pulp preconditioning on the content of polyphenols in cocoa beans (Theobroma cacao) during fermentation. Ind. Crop. Prod. 24, 87-94. https://doi.org/10.1016/j.indcrop.2006.03.013 (2006).

11. Caligiani, A., Cirlini, M., Palla, G., Ravaglia, R. \& Arlorio, M. GC-MS detection of chiral markers in cocoa beans of different quality and geographic origin. Chirality 19, 329-334. https://doi.org/10.1002/chir.20380 (2007).

12. Payne, M. J., Hurst, W. J., Miller, K. B., Rank, C. \& Stuart, D. A. Impact of fermentation, drying, roasting, and dutch processing on epicatechin and catechin content of cacao beans and cocoa ingredients. J. Agric. Food Chem. 58(19), 10518-10527 (2010).

13. Kongor, J. E. et al. Factors influencing quality variation in cocoa (Theobroma cacao) bean flavour profile: A review. Food Res. Int. 82, 44-52. https://doi.org/10.1016/j.foodres.2016.01.012 (2016)

14. Jinap, S., Jamilah, B. \& Nazamid, S. Sensory properties of cocoa liquor as affected by polyphenol concentration and duration of roasting. Food Qual. Prefer. 15(5), 403-409. https://doi.org/10.1016/s0950-3293(03)00097-1 (2004).

15. Voigt, J., Heinrichs, H., Voigt, G. \& Biehl, B. Cocoa-specific aroma precursors are generated by proteolytic digestion of the vicilinlike globulin of cocoa seeds. Food Chem. 50(2), 177-184. https://doi.org/10.1016/0308-8146(94)90117 (1994).

16. Biehl, B., Brunner, E., Passern, D., Quesnel, V. C. \& Adomako, D. Acidification, proteolysis and flavour potential in fermenting cocoa beans. J. Sci. Food Agric. 36, 583-598. https://doi.org/10.1002/jsfa.2740360710 (1985).

17. Biehl, B., Voigt, J., Heinrichs, H., Senjuk, V. \& Bytof, G. pH dependent enzymatic formation of oligopeptides and amino acids, the aroma precursors in raw cocoa beans. In Proceedings XIth International Cocoa Research Conference (ed. Lafforest, J.) 717-722 (Cocoa Producers' Alliance, 1993).

18. Kratzer, U. et al. Subunit structure of the vicilin-like globular storage protein of cocoa seeds and the origin of cocoa- and chocolatespecific aroma precursors. Food Chem. 113, 903-913. https://doi.org/10.1016/j.foodchem.2008.08.017 (2009).

19. Vella, A. et al. High hydroxycinnamic acids contents in fennel honey produced in Southern Italy. Nat. Prod. Res. https://doi.org/ $10.1080 / 14786419.2020 .1723090(2020)$.

20. Durazzo, A., Lucarini, M. \& Santini, A. Nutraceuticals in Human Health. Foods 3(9), 370. https://doi.org/10.3390/foods9030370 (2020).

21. Andújar, I., Recio, M. C., Giner, R. M. \& Ríos, J. L. Cocoa polyphenols and their potential benefits for human health. Oxid. Med. Cell. Longev. https://doi.org/10.1155/2012/906252 (2012).

22. Manach, C., Scalbert, A., Morand, C., Rémés, C. \& Jiménez, L. Polyphenols: Food sources and bioavailability. Am. J. Clin. Nutr. 79, 727-747. https://doi.org/10.1093/ajcn/79.5.727 (2004).

23. Misnawi, S. J., Nazamid, S. \& Jamilah, B. Activation of remaining key enzymes in dried under-fermented cocoa beans and its effect on aroma precursor formation. Food Chem. 78(4), 407-417. https://doi.org/10.1016/s0308-8146(02)00120-6 (2002).

24. Ooi, T. S., Ting, A. S. Y. \& Siow, L. F. Influence of selected native yeast starter cultures on the antioxidant activities, fermentation index and total soluble solids of Malaysia cocoa beans: A simulation study. LWT 122, 108977. https://doi.org/10.1016/j.lwt.2019. $108977(2020)$

25. Portillo, E., Graziani, L. \& Betancourt, E. Análisis Químico del Cacao Criollo porcelana (Theobroma cacao L.) en el Sur del Lago de Maracaibo. Rev. Fac. Agron. (LUZ) 24(3), 522-546 (2007).

26. Wacher, M. C. Microorganismos y chocolate. Rev. Digit. Univ. 12(4), 1-9. ISSN: 1607-6079 http://www.revista.unam.mx/vol.12/ num4/art42/index.html. Accessed 4 October 2020 (2011).

27. Romero, C. \& Zambrano, A. Análisis de azúcares en pulpa de cacao por colorimetría y electroforesis capilar. Rev. Cien. UDO Agríc. 12(4), 906-913 (2012).

28. Schwan, R. F. \& Wheals, A. E. The microbiology of cocoa fermentation and its role in chocolate quality. Crit. Rev. Food Sci. Nutr. 44(4), 205-221. https://doi.org/10.1080/10408690490464104 (2004).

29. Pinzón, J. O. et al. El proceso de Beneficio del cacao. Guía técnica para el Cultivo de cacao 5th edn, 152-164 (FEDECACAO, 2012).

30. Apriyanto, M., Sutardi, S. \& Harmayani, E. Study on effect of fermentation to the quality parameter of cocoa bean in Indonesia. Asian J Dairy Food Res. 35(2), 160-163. https://doi.org/10.18805/ajdfr.v35i2.10724 (2016).

31. Peláez, P. P., Guerra, S. \& Contreras, D. Changes in physical and chemical characteristics of fermented cocoa (Theobroma cacao) beans with manual and semi-mechanized transfer, between fermentation boxes. Sci. Agropecu. 07(02), 111-119. https://doi.org/ 10.17268/sci.agropecu.2016.02.04 (2016).

32. Graziani de Fariñas, L., Ortiz de Bertorelli, L. \& Lemus, M. Effect of mixing two types of grains cocoas on chemical characteristics during fermentation. Agron. Trop. 52(3), 325-342 (2002).

33. De Vuyst, L. \& Weckx, S. The cocoa bean fermentation process: from ecosystem analysis to starter culture development. J. Appl. Microbiol. 121, 5-17. https://doi.org/10.1111/jam.13045 (2016).

34. Lima, L. J. R., Almeida, M. H., Nout, M. J. R. \& Zwietering, M. H. Theobroma cacao L., "The Food of the Gods": Quality determinants of commercial cocoa beans, with particular reference to the impact of fermentation. Crit. Rev. Food Sci. Nutr. 51(8), 731-761. https://doi.org/10.1080/10408391003799913 (2011).

35. Schwan, R. \& Fleet, G. (eds) Cocoa and Coffee Fermentations (CRC Press, 2015). 
36. Jackels, S. C. \& Jackels, C. F. Characterization of the coffee mucilage fermentation process using chemical indicators: A field study in Nicaragua. J. Food Sci. Technol. 70(5), 321-325. https://doi.org/10.1111/j.1365-2621.2005.tb09960.x (2005).

37. Afoakwa, E. O., Paterson, A., Fowler, M. \& Ryan, A. Flavour formation and character in cocoa and chocolate: A critical review. Crit. Rev. Food Sci. Nutr. 48, 840-857. https://doi.org/10.1080/10408390701719272 (2008).

38. Biehl, B., Passern, D. \& Sagemann, W. Effect of acetic acid on subcellular structures of cocoa bean cotyledons. J. Sci. Food Agric. 33(11), 1101-1109. https://doi.org/10.1002/jsfa.2740331107 (2006).

39. Aremu, C. Y., Agiang, M. A. \& Ayatse, J. O. I. Nutrient and antinutrient profiles of raw and fermented cocoa beans. Plant Food Hum. Nutr. 48(3), 217-223. https://doi.org/10.1007/bf01088443 (1995).

40. Afoakwa, E. O. Chocolate Science and Technology (Wiley, 2016).

41. Torres-Moreno, M., Torrescasana, E., Salas-Salvadó, J. \& Blanch, C. Nutritional composition and fatty acids profile in cocoa beans and chocolates with different geographical origin and processing conditions. Food Chem. 166, 125-132. https://doi.org/10.1016/j. foodchem.2014.05.141 (2015).

42. Lehninger, A., Nelson, D. L. \& Cox, M. M. Principios de Bioquímica (Omega, 2006).

43. Lupano, C. E. Modificaciones de Componentes de los Alimentos: Cambios Químicos y Bioquímicos por Procesamiento y Almacenamiento (Universidad Nacional de La Plata, 2013).

44. Puerta, G. I. Efecto de enzimas pectolíticas en la remoción del mucílago del Coffea arabica L, según el desarrollo del fruto. Cenicafé 60(4), 291-312 (2009).

45. Rusconi, M. \& Conti, A. Theobroma cacao L., the Food of the Gods: A scientific approach beyond myths and claims. Pharmacol. Res. 61, 5-13. https://doi.org/10.1016/j.phrs.2009.08.008 (2010).

46. Marseglia, A. et al. Extraction, identification and semi-quantification of oligopeptides in cocoa beans. Food Res. Int. 63, 382-389. https://doi.org/10.1016/j.foodres.2014.03.046 (2014).

47. Miller, K. B. et al. Antioxidant activity and polyphenol and procyanidin contents of selected commercially available. J. Agric. Food. Chem. 54(11), 4062-4068. https://doi.org/10.1021/jf0602900 (2006).

48. Perea, V. A., Martínez, G. N., Aranzazú, H. F. \& Cadena, C. T. Características de Calidad de Cacao de Colombia Catálogo de 26 cultivares (No. 633.7413/P434) 2nd edn. (Universidad Industrial de Santander, Federación Nacional de Cacaoteros, 2017).

49. Di Mattia, C. et al. Effect of fermentation and drying on procyanidins, antiradical activity and reducing properties of cocoa beans. Food Bioprocess. Technol. 6(12), 3420-3432. https://doi.org/10.1007/s11947-012-1028-x (2013).

50. Adamson, G. E. et al. HPLC method for the quantification of procyanidins in cocoa and chocolate samples and correlation to total antioxidant capacity. J. Agric. Food Chem. 47(10), 4184-4188. https://doi.org/10.1021/jf990317 (1999).

51. Cádiz, M. L. et al. Isolation, comprehensive characterization and antioxidant activities of Theobroma cacao extract. J. Funct. Foods 10, 485-498. https://doi.org/10.1016/j.jff.2014.07.016 (2014).

52. del Brunetto, M. R. et al. Determination of theobromine, theophylline and caffeine in cocoa samples by a high-performance liquid chromatographic method with on-line sample cleanup in a switching-column system. Food Chem. 100(2), 459-467 (2007).

53. Davrieux, F., Assemat, S., Boulanger, R. \& Cross, E. Determination of cocoa purine content by near infrared spectroscopy. XIV International 14th International Cocoa Research Conference. Ghana, Poster Presentation. (2004).

54. Palacios, A. Establecimientos de Parámetros (Físicos, químicos y organolépticos) Para Diferenciar y Valorizar el Cacao (Theobroma Cacao L.) Producido en dos zonas Identificadas al norte y sur del Litoral Ecuatoriano. Tesis para optar al título de ingeniera agrónoma 136 (Universidad Técnica de Manabí, 2008).

55. Ascrizzi, R., Flamini, G., Tessieri, C. \& Pistelli, L. From the raw seed to chocolate: Volatile profile of Blanco de Criollo in different phases of the processing chain. Microchem. J. 133, 474-479. https://doi.org/10.1016/j.microc.2017.04.024 (2017).

56. IDEAM. Atlas climatológico de Colombia (1981-2010). Interactivo. (Instituto de Hidrología, Meteorología y Estudios Ambientales, 2015). http://atlas.ideam.gov.co/visorAtlasClimatologico.html. Accessed 4 October 2020.

57. Gómez, L., Caballero, A. \& Baldión, J. V. Ecotopos Cafeteros de Colombia 131 (FNC, 1991).

58. AOAC. Official Methods of Analysis of the Association of Official Analytical Chemists. AOAC Official Method 932.12 Solids (Soluble) in Fruits and Fruit Products 20th edn. (AOAC. INTERNACIONAL, Rockville, 2016).

59. Murillo, C., Villamizar, A., Pico, S., Jaimes, J. \& López, L. Implementación de un método analítico por cromatografía líquida para evaluar la calidad en mieles del nororiente colombiano. Alimentos Hoy 25(40), 32-42 (2017).

60. AOAC. Official methods of Analysis of the Association of Official Analytical Chemists. AOAC Official Method 942.15 Acidity (Titratable) of Fruit Products 18th edn. (AOAC INTERNACIONAL, 2005).

61. AOAC. Official Methods of Analysis of the Association of Official Analytical Chemists. AOAC Offcial Method 943.02. pH in food 18th edn. (AOAC INTERNACIONAL, 2005).

62. AOAC. Official Methods of Analysis of the Association of Official Analytical Chemists. AOAC Offcial Method 942.05. Ash of Animal Feed 20th edn. (AOAC INTERNACIONAL, 2016).

63. AOAC. Official methods of Analysis of the Association of Official Analytical Chemists. AOAC Official Method 960.52. Microchemical Determination of Nitrogen: Micro-Kjeldahl Method 20th edn. (AOAC INTERNACIONAL, 2016).

64. AOAC. Official methods of Analysis of the Association of Official Analytical Chemists. AOAC Official Method 963.15 Fat in Cacao Products 20th edn. (AOAC INTERNACIONAL, 2016).

65. Wollgast, J. The Contents and Effects of Polyphenols in Chocolate Qualitative and Quantitative Analyses of Polyphenols in Chocolate and Chocolate Raw Products as well as Evaluation of Potential Implications of Chocolate Consumption in Human Health. Ph.D. thesis. Giessen, Germany. Justus Liebig University Giessen 349 (2004).

66. Carrillo, L. C., Londoño-Londoño, J. \& Gil, A. Comparison of polyphenol, methylxanthines and antioxidant activity in Theobroma cacao beans from different cocoa-growing areas in Colombia. Food Res. Int. 60, 273-280. https://doi.org/10.1016/j.foodres.2013. 06.019 (2014).

67. Sharma, O. P. \& Bhat, T. K. Analytical methods DPPH antioxidant assay revisited. Food Chem. 113(4), 1202-1205. https://doi.org/ 10.1016/j.foodchem.2008.08.008 (2009).

\section{Acknowledgements}

The authors express their appreciation to the Colombian Corporation of Agricultural Research, AGROSAVIA and to the Colombian Ministry of Agriculture and Rural Development for funding the project "Dynamics of biochemical profiles in the cacao fermentation process in a model farm", from which this study was derived.

\section{Author contributions}

B.L.B.: Investigation, writing methodology and analyze the data; A.M.C.: Investigation, writing draft results, revising the article; W.A.C.: Data Curation, software, statistical analysis, writing analysis; A.C.M.: chemical analysis, interpreting chemical analysis; J.C.: conceptualization, design, sensory analysis, writing discussion and M.C.G.: Conceptualization, methodology, formal analysis, writing results, discussion, and approval final version. 


\section{Competing interests}

The authors declare no competing interests.

\section{Additional information}

Supplementary Information The online version contains supplementary material available at https://doi.org/ 10.1038/s41598-021-95703-2.

Correspondence and requests for materials should be addressed to M.C.G.

Reprints and permissions information is available at www.nature.com/reprints.

Publisher's note Springer Nature remains neutral with regard to jurisdictional claims in published maps and institutional affiliations.

(c) (1) Open Access This article is licensed under a Creative Commons Attribution 4.0 International License, which permits use, sharing, adaptation, distribution and reproduction in any medium or format, as long as you give appropriate credit to the original author(s) and the source, provide a link to the Creative Commons licence, and indicate if changes were made. The images or other third party material in this article are included in the article's Creative Commons licence, unless indicated otherwise in a credit line to the material. If material is not included in the article's Creative Commons licence and your intended use is not permitted by statutory regulation or exceeds the permitted use, you will need to obtain permission directly from the copyright holder. To view a copy of this licence, visit http://creativecommons.org/licenses/by/4.0/.

(C) The Author(s) 2021 